\title{
Occurrence of respiratory disease outbreaks in fattening pigs: Relation with the features of a densely and a sparsely populated pig area in France
}

\author{
Nicolas RosE*, François MAdeC \\ AFSSA-Ploufragan, BP 53, 22440 Ploufragan, France \\ (Received 26 March 2001; accepted 8 October 2001)
}

\begin{abstract}
A survey was carried out in France in 1999 in a Densely Populated Pig Area (DPPA) and a Sparsely Populated Pig Area (SPPA) from which 80 and 55 pig farms were respectively investigated. The two areas were compared regarding the number of respiratory disease outbreaks in fattening pigs on each farm per year with a multiple correspondence analysis and hierarchical clustering. The two areas exhibited different typologies: in the DPPA, high density was associated with a high proportion of finishing-pig units resulting in much moving of piglets within the area. Farrow-to-finish farms located in the DPPA had many contacts with external vehicles; this was associated with more than two respiratory disease outbreaks per farm per year. There also was a lack of biosecurity measures implemented on these farms. Conversely, the good health situation of the farms located in the SPPA was associated with few external contacts and good biosecurity measures. In a second step, risk factors for the occurrence of more than 2 respiratory outbreaks per year were studied. Having more than 4 pig farms within a $2 \mathrm{~km}$ radius area, more than 30 incoming rendering trucks per year, and storage of the carcasses of dead animals within the farmyard perimeter increased the risk of occurrence of more than 2 respiratory disease outbreaks per year on the farm. This risk was also increased when there were more than 2 animal-transport lorries entering the farm per month and more than 1 veterinarian's or technician's vehicle coming in every 2 months. These results were discussed because of possible bias due to the retrospective design of the survey and the sampling scheme (randomisation within two areas).
\end{abstract}

finishing pig / respiratory disease / pig density / farm profile / biosecurity

Résumé - Syndromes grippaux en porcherie d'engraissement : relation avec les caractéristiques d'une zone à forte et faible densité porcine en France. Une zone à basse densité (BD) et une zone à forte densité (FD) ont été enquêtées en France en 1999 dans lesquelles 55 et 80 porcheries, respectivement, ont été étudiées. Les typologies de ces deux zones ont été comparées au regard du statut sanitaire

*Correspondence and reprints

Tel.: (33) 296016 222; fax: (33) 296016 253; e-mail: n.rose@ploufragan.afssa.fr 
des élevages (nombre d'épisodes de type grippal en engraissement) au moyen d'une analyse factorielle des correspondances multiples suivie d'une classification ascendante hiérarchique. Les deux zones présentaient une typologie différente : en zone $\mathrm{FD}$, la forte densité était associée à un nombre d'élevages plus important de type engraisseur, impliquant une circulation des porcelets plus importante. La forte fréquentation des élevages naisseur-engraisseurs situés dans cette zone par les véhicules extérieurs, peut être interprétée en tant que cause ou conséquence d'une situation sanitaire difficile (nombre de syndromes grippaux en engraissement $>2$ par an), exacerbée par le manque de précautions sanitaires prises par ces mêmes élevages. En zone BD, la bonne situation sanitaire des élevages à l'égard de la pathologie cible, était associée à une faible fréquentation par les véhicules extérieurs et à la mise en place de mesures de biosécurité. Dans un second temps, les facteurs de risque de l'expression clinique de plus de 2 syndromes grippaux par an ont été recherchés. Le modèle de régression logistique a permis de mettre en évidence que la densité d'élevages porcins autour de l'exploitation (plus de quatre élevages de porcs dans un rayon de $2 \mathrm{~km}$ ), une fréquentation importante de l'élevage par les véhicules d'équarrissage ( $>30$ passages par an) et le stockage des cadavres dans le périmètre de l'exploitation augmentent significativement le risque de survenue de plus de deux syndromes grippaux par an chez les porcs à l'engrais. Le risque est aussi augmenté lorsque la fréquentation par les véhicules de transport d'animaux d'une part et par le vétérinaire ou le technicien d'autre part est importante (plus de deux passages par mois et plus d'un passage tous les deux mois respectivement). Ces résultats sont discutés compte tenu de la nature de l'étude (rétrospective) et des spécificités liées à l'échantillonnage (tirage au sort dans deux zones sélectionnées).

porc / syndrome grippal / densité porcine / typologie / biosécurité

\section{INTRODUCTION}

Intensification of the pig industry has exerted great pressure on the health status of pigs and respiratory diseases constitute the main cause of economic loss for the farmers [16]. The classic viral diseases of pigs (Aujeszky's disease, Porcine Reproductive and Respiratory Syndrome [PRRS], Influenza) can be complicated by bacterial agents (Actinobacillus pleuropneumoniae, Pasteurella multocida, Mycoplasma hyopneumoniae) leading to considerable losses on farms with poor rearing conditions. These infectious agents cause acute respiratory-disease outbreaks in fattening pigs [13] (association of anorexia, fever $\left[40^{\circ} \mathrm{C}\right.$ to $41{ }^{\circ} \mathrm{C}$ ] for at least 2 days, and paroxysmal cough [14]). This syndrome can remain subclinical on farms with a high standard of hygiene whereas an acute clinical outbreak is observed on farms with a heavy microbial load. The severity of a respiratory-disease outbreak is an indicator of farm health status [15].
Pig density is a risk factor for spreading viral diseases: (1) Aujeszky's disease [9, 12, 19, 23], (2) PRRS [1, 3], and (3) Influenza $[7,14,15,17,18]$. However, the specific features of these densely populated areas might explain the increased risk of spread of the above viral agents. Pig density partly explains the geographical distribution of farms seropositive for Aujeszky's disease in Brittany [2]. This study suggests that pig density is important but not sufficient to describe the structure of pig production in an area and the crude effect of pig density might be modified by other characteristics of the area (movement of the animals, rearing practices, etc.). Thus, the description and comparison of two areas selected for contrasting pig densities might be a useful approach for determining the specific profile of densely populated areas which possibly lead to an increased risk of introduction and spread of viral diseases.

The aim of our study was therefore to describe and compare the features of a densely populated pig area and a sparsely 
populated one with regard to management characteristics and pig farm health status measured from the number of respiratory disease outbreaks occurring per year in finishing pigs. In a second part, possible risk factors, adjusted for the geographical area, and related to the occurrence of two or more respiratory disease outbreaks per year on the farm were investigated.

\section{MATERIALS AND METHODS}

\subsection{Study sample}

The "canton" of Plouguenast (department of Côtes-d'Armor) was selected as the densely populated pig area (DPPA) and the "cantons" of Huelgoat and Chateauneuf du Faou (department of Finistère) as the sparsely populated pig area (SPPA) (Tab. I, Fig. 1). An exhaustive list of pig farms located in the two areas was obtained from the Veterinary Services of both counties and from the "farmers Union", a private organisation (Union des Groupements de Producteurs de Viande de Bretagne). Seventy percent of the pig farms in each area were selected at random, resulting in a sample of 100 farms for the DPPA and 70 farms for the SPPA. Due to refusals and termination of activity, 80 questionnaires were finally obtained from the DPPA and 55 from the

Table I. General characteristics of selected areas

\begin{tabular}{|c|c|c|}
\hline & $\mathrm{DPPA}^{\mathrm{a}}$ & $\operatorname{SPPA}^{\mathrm{b}}$ \\
\hline Agricultural area $\left(\mathrm{km}^{2}\right)$ & 169 & 609 \\
\hline Pig density $\left(\mathrm{pigs} / \mathrm{km}^{2}\right.$ ) & 780 & 99 \\
\hline No. of investigated farms & 80 & 55 \\
\hline \multicolumn{3}{|c|}{$\begin{array}{l}\text { a Densely Populated Pig Area (canton of Plouguenast, } \\
\text { Côtes-d'Armor, France). } \\
\text { b Sparsely Populated Pig Area (canton of Huelgoat } \\
\text { and Chateauneuf du Faou, Finistère, France). } \\
{ }^{c} \text { Every pig }>30 \mathrm{~kg} \text { liveweight. }\end{array}$} \\
\hline
\end{tabular}

SPPA. The proportion of refusals was similar for the two areas (20\% for DPPA vs. $21.4 \%$ for SPPA) and was mainly related to termination of activity.

\subsection{Data collection}

We phoned the selected farmers to explain the aim of the study and make an appointment. A single interviewer filled in the questionnaire with the farmer at the farm site. The questionnaire had previously been tested on 15 farms and contained 95 closeended questions. All the questionnaires were collected from March to October 1999. The main items included interviewee characteristics, a description of the farm site, rearing conditions, animal movements (purchases / sales), incoming vehicles, farm staff and visitors and herd size. The criterion retained as the outcome variable was the number of respiratory disease outbreaks that occurred in 1998. Only typical acute and collective outbreaks were retained that included anorexia, fever for at least $48 \mathrm{~h}$ and paroxysmal cough.

\subsection{Statistical procedure}

\subsubsection{Features of the DPPA and SPPA}

We used a multiple correspondence analysis followed by hierarchical clustering [22]. The main objective in this analysis is to detect the associations within a set of categorical variables in a small number of dimensions, and to give a low-dimensional (often two-dimensional) graphical representation of these associations [4]. To complete the analysis and to facilitate the interpretation of the factorial maps derived from the correspondence analysis, the classification process builds clusters of subjects based on the degree of similarity between the individuals with regards to the variables $[8,11]$. This method is quite similar to a principal component analysis. Both methods have the same aim: to build typologies 


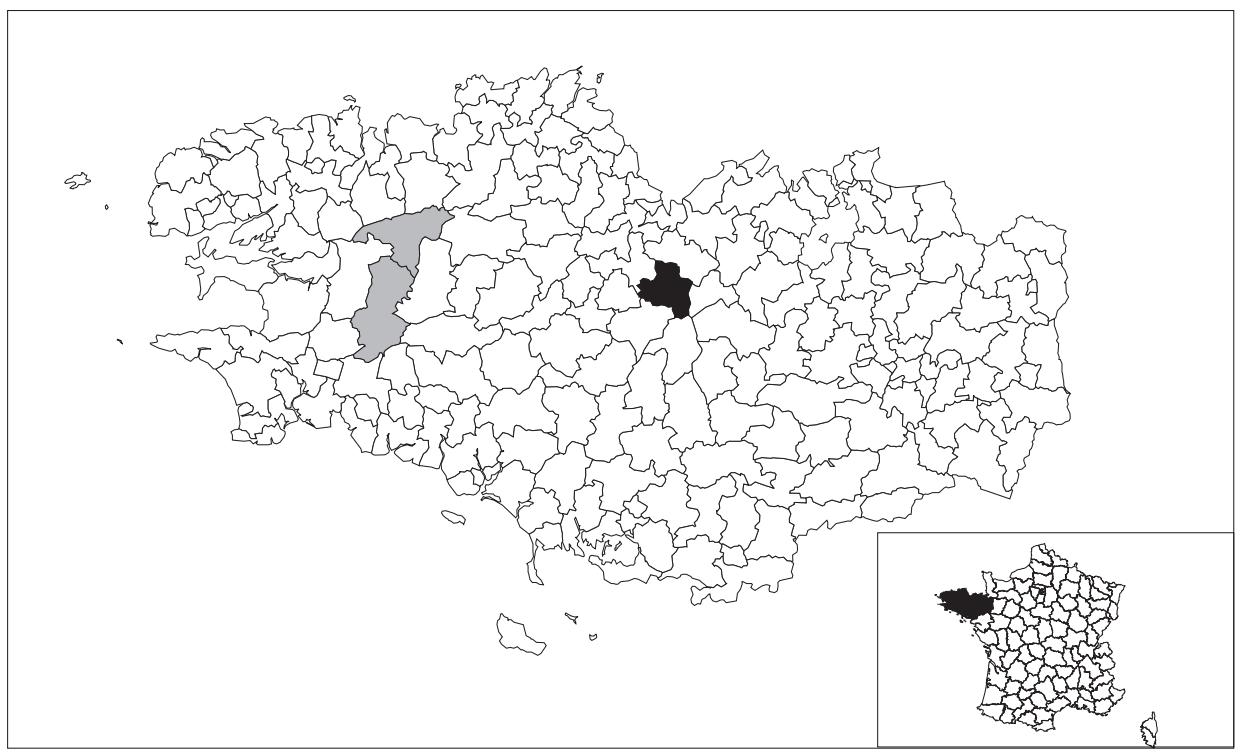

Figure 1. Map of Brittany, localisation of the selected areas: densely populated pig area (canton of Plouguenast) and sparsely populated pig area (cantons of Huelgoat and Chateauneuf du Faou).

of individuals with data grouped within a table (Individuals $\times$ Variables) and where variables are categories, whereas they are continuous in Principal Component Analysis. This typology is based on a distance principle, so that the closer the individuals are to each other, the larger are the number of categories they share together.

In a preliminary step, an initial screening of the variables possibly related to the area (DPPA vs. SPPA) was performed using the FREQ procedure [21]. Only those variables related to the area $(p<0.20)$ were included in the multiple correspondence analysis. Finally 21 active variables (split into 57 categories) were introduced into the analysis. The "area" variable (DPPA vs. SPPA) was included as a supplementary variable so that it was not included in the definition of factorial axes. In the hierarchical clustering, only those variables that were significantly related $\left(\chi^{2}\right.$-test, $\left.p<0.05\right)$ to each group were retained to describe the clusters.

\subsubsection{Risk factors for the occurrence of 2 or more respiratory disease outbreaks per year}

\subsubsection{Outcome and explanatory variables}

The unit of observation was the farm. A case was defined as a farm that experienced 2 or more respiratory disease outbreaks during 1998. For possible explanatory variables, the number of categories per variable was limited such that the category frequencies were $>10 \%$ (Tab. II). The variables under study were selected during a preliminary step to reduce the chance of obtaining results affected by multicolinearity within the dataset [4]. All bivariable relationships between possible explanatory variables were $\operatorname{checked}\left(\chi^{2}\right.$-test). For those relationships between variables that exhibited strong structural collinearity $(P<0.05)$, one of the two variables of interest (the one we believed to be most related to the outcome variable) was chosen. 
Table II. Definition of explanatory variables included in the analysis of the occurrence of 2 or more respiratory disease outbreaks/year and percentage of farms for each level of the variables (135 pig farms).

\begin{tabular}{|c|c|c|}
\hline Definition of variables & Level & Percentage $(\%)$ \\
\hline \multirow[t]{2}{*}{ Rearing of cattle on the farm } & No & 34.8 \\
\hline & Yes & 65.2 \\
\hline \multirow[t]{3}{*}{ Fence around the farm yard perimeter } & None & 65.2 \\
\hline & For some areas only & 21.5 \\
\hline & All around the farm & 13.3 \\
\hline \multirow{3}{*}{$\begin{array}{l}\text { Sharing of the manure spreader with other } \\
\text { farms }\end{array}$} & No & 45.9 \\
\hline & Yes, without cleaning & 34.1 \\
\hline & Yes, but cleaning before use & 20.0 \\
\hline \multirow{2}{*}{$\begin{array}{l}\text { Storage of carcasses inside the farm yard } \\
\text { perimeter }^{\text {a }}\end{array}$} & No & 30.4 \\
\hline & Yes & 69.6 \\
\hline \multirow[t]{3}{*}{ Veterinary assistance } & Farm veterinarian & 33.1 \\
\hline & Consultant veterinarian & 23.3 \\
\hline & Both & 43.6 \\
\hline \multirow[t]{2}{*}{ Using a quarantine for the pigs introduced } & No & 53.3 \\
\hline & Yes & 46.7 \\
\hline \multirow{2}{*}{$\begin{array}{l}\text { Pigs are sold to other farms or fattened on } \\
\text { other farms }\end{array}$} & No & 83.7 \\
\hline & Yes & 16.3 \\
\hline \multirow{2}{*}{$\begin{array}{l}\text { Average number of animal transport vehicles } \\
\text { entering the farm }\end{array}$} & $\leq 2$ per month & 37.8 \\
\hline & $>2$ per month & 62.2 \\
\hline \multirow{2}{*}{$\begin{array}{l}\text { Average number of feed vehicles entering the } \\
\text { farm }^{\mathrm{a}}\end{array}$} & $\leq 2$ per month & 44.4 \\
\hline & $>2$ per month & 55.6 \\
\hline \multirow{2}{*}{$\begin{array}{l}\text { Number of veterinarian or technician vehicles } \\
\text { entering the farm }{ }^{\mathrm{a}}\end{array}$} & $\leq 1$ every 2 months & 28.9 \\
\hline & $>1$ every 2 months & 71.1 \\
\hline \multirow[t]{2}{*}{ Number of dealer vehicles entering the farm ${ }^{a}$} & None & 27.4 \\
\hline & 1 per month at least & 72.6 \\
\hline \multirow{2}{*}{$\begin{array}{l}\text { Number of external manure vehicles entering } \\
\text { the farm }{ }^{\mathrm{a}}\end{array}$} & $<1$ every 2 months & 76.3 \\
\hline & $\geq 1$ every 2 months & 23.7 \\
\hline \multirow[t]{2}{*}{ The milk truck comes onto the farm } & No & 51.1 \\
\hline & Yes & 48.9 \\
\hline \multirow{2}{*}{$\begin{array}{l}\text { Number of rendering plant lorries } \\
\text { entering the farm }{ }^{\mathrm{a}}\end{array}$} & $\leq 30$ per year & 69.6 \\
\hline & $>30$ per year & 30.4 \\
\hline \multirow{2}{*}{$\begin{array}{l}\text { Use of a vehicle shared with other farms for } \\
\text { animal transport }\end{array}$} & No & 86.5 \\
\hline & Yes & 13.5 \\
\hline \multirow[t]{3}{*}{ Presence of a loading area for pigs } & No & 14.8 \\
\hline & Yes, but never cleaned & 43.7 \\
\hline & Yes, cleaned after each operation & 41.5 \\
\hline
\end{tabular}

\footnotetext{
${ }^{\text {a }}$ Variable retained at screening step to be offered to a logistic model $(P<0.25)$.
} 
Table II (continued)

\begin{tabular}{|c|c|c|}
\hline Definition of variables & Level & Percentage $(\%)$ \\
\hline Number of stock persons on the farm & $\begin{array}{c}1 \\
2 \\
\text { more than } 2\end{array}$ & $\begin{array}{l}24.5 \\
42.2 \\
33.3\end{array}$ \\
\hline $\begin{array}{l}\text { Employees: part-time shared with other } \\
\text { pig farms }\end{array}$ & $\begin{array}{l}\text { No } \\
\text { Yes }\end{array}$ & $\begin{array}{l}59.3 \\
40.7\end{array}$ \\
\hline Frequency of coveralls laundry & $\begin{array}{c}<\text { once a week } \\
\text { once a week } \\
>\text { once a week }\end{array}$ & $\begin{array}{l}44.4 \\
44.5 \\
11.1\end{array}$ \\
\hline $\begin{array}{l}\text { Employees from feed companies are } \\
\text { allowed to enter the facilities }\end{array}$ & $\begin{array}{l}\text { No } \\
\text { Yes }\end{array}$ & $\begin{array}{l}75.6 \\
24.4\end{array}$ \\
\hline $\begin{array}{l}\text { Hauliers are allowed to enter the } \\
\text { facilities }\end{array}$ & $\begin{array}{l}\text { No } \\
\text { Yes }\end{array}$ & $\begin{array}{l}83.7 \\
16.3\end{array}$ \\
\hline $\begin{array}{l}\text { Other farmers are allowed to enter the } \\
\text { facilities }^{\mathrm{a}}\end{array}$ & $\begin{array}{l}\text { No } \\
\text { Yes }\end{array}$ & $\begin{array}{l}84.4 \\
15.6\end{array}$ \\
\hline $\begin{array}{l}\text { Disinfection of the boots of visitors } \\
\text { before entering the facilities }\end{array}$ & $\begin{array}{l}\text { No } \\
\text { Yes }\end{array}$ & $\begin{array}{l}71.1 \\
28.9\end{array}$ \\
\hline Specific coverall for visitors & $\begin{array}{l}\text { No } \\
\text { Yes }\end{array}$ & $\begin{array}{l}18.5 \\
81.5\end{array}$ \\
\hline Visitors wear a cap to enter the facilities & $\begin{array}{l}\text { No } \\
\text { Yes }\end{array}$ & $\begin{array}{l}54.8 \\
45.2\end{array}$ \\
\hline $\begin{array}{l}\text { Access is restricted if visitors have been } \\
\text { in contact with other pig farms before } \\
\text { visiting the farm }\end{array}$ & $\begin{array}{l}\text { No } \\
\text { Yes }\end{array}$ & $\begin{array}{l}37.0 \\
63.0\end{array}$ \\
\hline $\begin{array}{l}\text { Number of pig farms located in a } 2 \mathrm{~km} \\
\text { radius area around the farm under study }\end{array}$ & $\begin{array}{l}\leq 4 \\
>4\end{array}$ & $\begin{array}{l}67.4 \\
32.6\end{array}$ \\
\hline $\begin{array}{l}\text { Number of fattening places in the farm } \\
\text { under study }{ }^{a}\end{array}$ & $\begin{array}{c}\leq 230 \\
] 230-400] \\
>400\end{array}$ & $\begin{array}{l}25.2 \\
25.9 \\
48.9\end{array}$ \\
\hline $\begin{array}{l}\text { Number of batches of pigs introduced } \\
\text { per year }{ }^{\mathrm{a}}\end{array}$ & $\begin{array}{l}\leq 4 \\
>4\end{array}$ & $\begin{array}{l}51.9 \\
48.1\end{array}$ \\
\hline Area $^{\mathrm{a}}$ & $\begin{array}{l}\text { Densely Populated Pig Area } \\
\text { Sparsely Populated Pig Area }\end{array}$ & $\begin{array}{l}59.3 \\
40.7\end{array}$ \\
\hline Farm system ${ }^{\mathrm{a}}$ & $\begin{array}{l}\text { Farrow-to-finish unit } \\
\text { Finishing unit }\end{array}$ & $\begin{array}{l}60.0 \\
40.0\end{array}$ \\
\hline
\end{tabular}

\footnotetext{
${ }^{\text {a }}$ Variable retained at screening step to be offered to a logistic model $(P<0.25)$.
} 


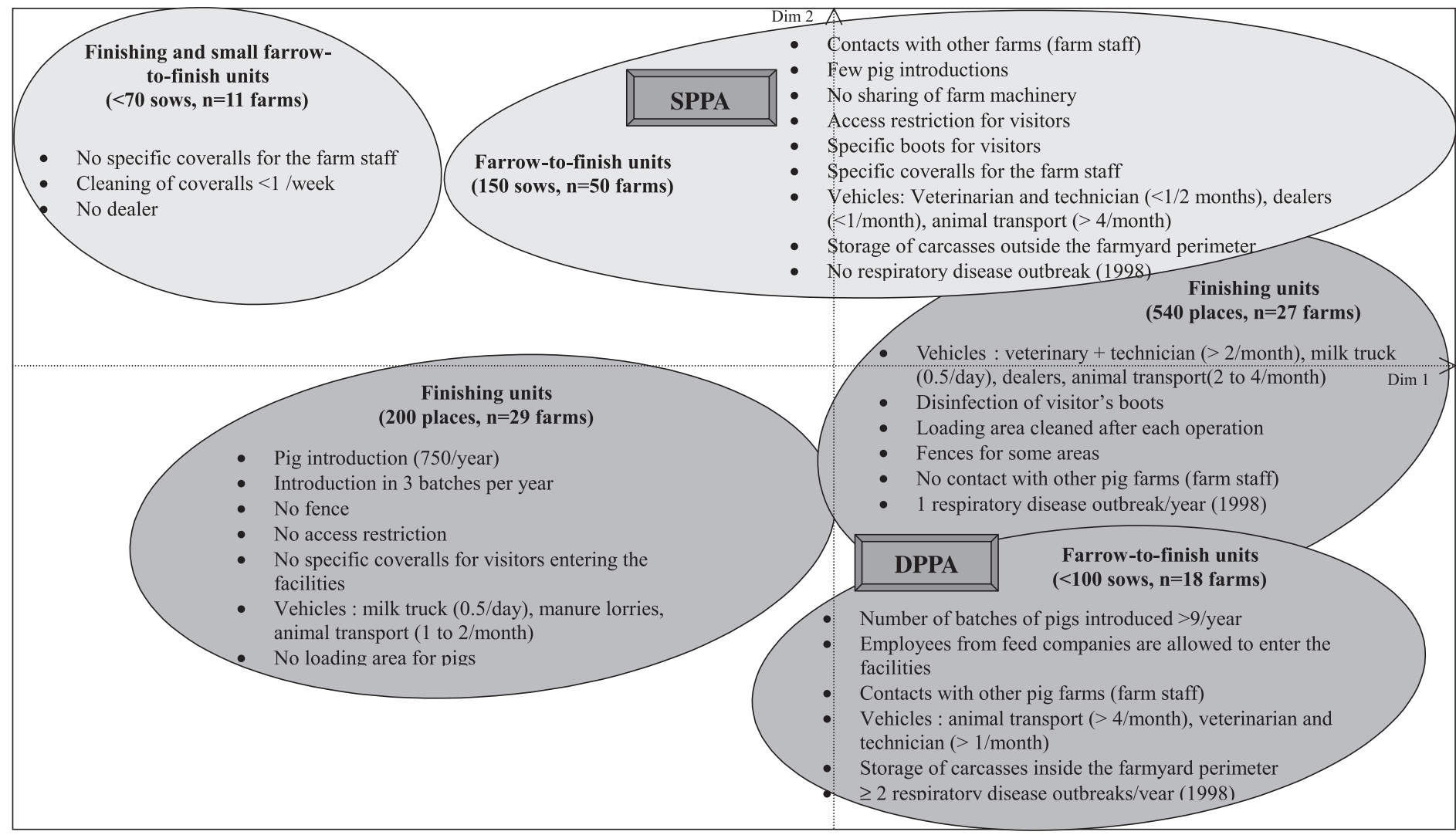

Figure 2. Multivariate description of the features of the pig farms (135 pig farms) - Dimensions 1-2 of the Multiple Correspondence Analysis. Features related to DPPA and SPPA . 21 active variables, 57 categories, 1 supplementary variable (DPPA/SPPA). 
Table III. Final logistic-regression model for risk factors for the occurrence of 2 or more respiratory disease outbreaks per year (135 pig farms).

\begin{tabular}{|c|c|c|c|}
\hline \multirow[b]{2}{*}{ Variables } & \multirow{2}{*}{$\begin{array}{l}\text { Percentage of farms with } \\
\geq 2 \text { outbreaks/year }(\%)\end{array}$} & \multicolumn{2}{|c|}{ Logistic model $^{\mathrm{a}}$} \\
\hline & & $\mathrm{OR}^{\mathrm{b}}$ & $\left(\mathrm{CI}^{\mathrm{c}} 90 \%\right)$ \\
\hline \multicolumn{4}{|l|}{ Farm system } \\
\hline Farrow-to-finish unit & 20.9 & 1.3 & $(0.4,3.9)$ \\
\hline Finishing unit & 12.9 & - & - \\
\hline \multicolumn{4}{|l|}{ Area } \\
\hline DPPA $^{d}$ & 22.5 & 2.0 & $(0.7,5.4)$ \\
\hline $\mathrm{SPPA}^{\mathrm{e}}$ & 10.9 & - & - \\
\hline \multicolumn{4}{|c|}{$\begin{array}{l}\text { Number of pig farms in a } 2 \mathrm{~km} \\
\text { radius area around the farm }\end{array}$} \\
\hline$\leq 4$ & 10.9 & - & - \\
\hline$>4$ & 31.8 & 2.9 & $(1.2,7.4)$ \\
\hline \multicolumn{4}{|c|}{$\begin{array}{l}\text { Storage of carcasses inside } \\
\text { the farm yard perimeter }\end{array}$} \\
\hline No & 9.8 & - & - \\
\hline Yes & 21.3 & 3.4 & $(1.1,10.4)$ \\
\hline \multicolumn{4}{|c|}{$\begin{array}{l}\text { Number of animal transport } \\
\text { vehicles entering the farm }\end{array}$} \\
\hline$\leq 2$ per month & 5.9 & - & - \\
\hline$>2$ per month & 25.0 & $5.1^{\mathrm{f}}$ & $(1.5,17.8)$ \\
\hline \multicolumn{4}{|c|}{$\begin{array}{l}\text { Number of rendering plant lorries } \\
\text { entering the farm }\end{array}$} \\
\hline$\leq 30$ per year & 10.6 & - & - \\
\hline$>30$ per year & 34.2 & $3.2^{\mathrm{f}}$ & $(1.3,8.1)$ \\
\hline \multicolumn{4}{|c|}{$\begin{array}{l}\text { Number of veterinarian or techni- } \\
\text { cian vehicles entering the farm }\end{array}$} \\
\hline$\leq 1$ every 2 months & 5.1 & - & - \\
\hline$>1$ every 2 months & 22.9 & $5.5^{\mathrm{f}}$ & $(1.4,21.6)$ \\
\hline
\end{tabular}

${ }^{\mathrm{a}}$ Intercept $=-5.65$, model deviance $=92.5, \mathrm{df}=7(p<0.001)$.

${ }^{\mathrm{b}}$ Odds ratios.

${ }^{\mathrm{c}}$ Confidence interval $(p<0.10)$.

${ }^{\mathrm{d}}$ Densely populated pig area.

e Sparsely populated pig area.

${ }^{\mathrm{f}}$ Significant also at $p<0.05$ (likelihood-ratio $\left(\chi^{2}\right.$-test).

\subsubsection{Model}

Logistic regression was used (proc LOGISTIC, [21]) according to the method described by Hosmer and Lemeshow [10]. In the first of the two steps, a univariable analysis related the outcome variable to each explanatory variable. Only factors associated with the outcome (likelihood-ratio $\left(\chi^{2}\right.$-test, $\left.P<0.25\right)$ were offered to the multivariate model (Tab. II). The second step involved a logistic multiple-regression 
model that included all factors that passed the first screening. The contribution of each factor to the model was tested using a likelihood-ratio chi-square test [20]. The variable with the highest $P$ was removed and the logistic regression was rerun. This process was continued until a model was obtained with all factors significant at $P<0.10$ (2-tailed). The variables farm system (Finishing/Farrow-to-finish) and geographical area (DPPA/SPPA) were forced into the model in order to adjust the estimation of the odds ratios according to these factors. All possible interactions between these forced variables and other significant factors were tested.

\section{RESULTS}

\subsection{Profiles of the DPPA and SPPA (Fig. 2)}

One hundred and thirty-five farms were included in the analysis and five clusters were obtained according to the hierarchical clustering. The cumulative percentage of inertia for the 3 first dimensions was $24.5 \%$. The DPPA was not homogenous with regards to farm characteristics. Three clusters were related to this area: (1) one group of small finishing units [bottom, left part of the map], (2) one group of larger finishing units [middle, right part of the map], and (3) one group of farrow-to-finish units [bottom, right part of the map]. The finishing units applied few biosecurity measures (no specific coveralls, no access restriction) and introduced a large number of pigs per year but in few batches. The number of vehicles entering the farm per month was moderate to high and these farms experienced few respiratory disease outbreaks per year ( $\leq 1 /$ year). In contrast, the farrowto-finish farms that were surrounded by all the previously described finishing units applied very poor biosecurity measures and had a high number of vehicles entering the farm per month. They experienced more than 2 respiratory disease outbreaks per year.

The SPPA was mainly described by a large cluster of farrow-to-finish farms [top, right part of the map] characterised by good biosecurity measures and a low frequentation by vehicles. These farms did not experience any respiratory disease outbreak during the year. Finally, a small group of 11 farms was also related to the SPPA. This group was represented by very small, isolated and marginal units where no biosecurity measure was applied.

\subsection{Risk factors for the occurrence of 2 or more respiratory disease outbreaks per year (Tab. III)}

Twenty-four (17.8\%) of the 135 farms under study experienced 2 or more respiratory disease outbreaks in 1998. Having more than 4 pig farms within a $2 \mathrm{~km}$ radius area $(\mathrm{OR}=2.9)$, more than 30 incoming rendering trucks per year $(\mathrm{OR}=3.2)$, and storage of the carcasses of dead animals within the farmyard perimeter $(\mathrm{OR}=3.4)$ increased the risk of occurrence of more than 2 respiratory disease outbreaks per year on the farm. This risk was also increased when there were more than 2 animal-transport lorries entering the farm per month $(\mathrm{OR}=5.1)$ and more than 1 veterinarian's or technician's vehicle coming in every 2 months $(\mathrm{OR}=5.5)$. Hosmer and Lemeshow's goodness-of-fit statistics indicated a good agreement of the predictive values with the observations ( $p=0.83)$. Interactions between the forced variables (farm system and geographical area) and the other variables included in the model were not significant.

\section{DISCUSSION}

The random selection of the farms led to good representativeness of the farms within each area and made the description of the 
features of each area possible. The proportion of refusals and their reasons did not differ between the two areas so that a comparison was possible. However, the 2 areas were not randomly chosen within the densely and sparsely populated areas of Brittany but were selected according to convenience criteria. Therefore, the results should not be generalised to DPPAs and SPPAs in France. Other areas might have been selected as the DPPA but we preferred to choose one with a mean pig density within the cantons of more than 500 pigs/ $\mathrm{km}^{2}$.

The pig farms located in the DPPA and SPPA did not have the same profile. Farms located in the DPPA were mainly finishing units, where pig production was often a supplementary activity to dairy cattle. Farrow-to-finish farms located in this area were mainly small units with a rather poor health status and where few biosecurity measures were applied. This situation might be explained by the presence of many finishing units in the area leading to numerous transfers of piglets that can increase the risk of virus spread as is suggested for Aujeszky's disease [2]. In the SPPA, larger farrow-to-finish farms were encountered with better biosecurity measures, fewer vehicle contacts and with a better health situation. Therefore, animal movements in association with animal density seem to be involved in the increased risk regarding the occurrence of respiratory disease outbreaks in finishing pigs.

In order to determine the potential risk factors related to the different health status observed on farms located in the DPPA and the SPPA, we decided to use the number of respiratory disease outbreaks that occurred on the farm during 1998 as an indicator. Only acute outbreaks were included and the extreme situations defined as those farms in which 2 or more respiratory disease outbreaks occurred within a year and those with 1 or no outbreak were compared. The diagnosis was made by the farmer and pos- sible recall bias may have occurred. However farmers are very used to these kinds of respiratory outbreaks and both the fact that the data were collected by only one person and that only extreme situations were retained ( $\geq 2$ respiratory outbreaks/year) may have contributed to a good precision of the result. We only took into account collective outbreaks [13] where more than $80 \%$ of the pigs within a batch were affected; thus confusion with other enzootic respiratory diseases was not possible. The outcome was thus defined upon clinical evaluation and the farm could be infected by several viral or bacterial agents responsible for this syndrome: Aujeszky's disease virus, Influenza viruses, Porcine Respiratory Coronavirus, PRRS virus or to a certain extent Actinobacillus pleuropneumoniae [6]. However, on farms with poor hygiene conditions, infection by these agents is often complicated by secondary infections leading to an acute clinical outbreak: primary infection by Aujeszky's disease virus followed by Actinobacillus pleuropneumoniae, or successive contamination by Influenza viruses [5]. The severity of the clinical expression of this syndrome in finishing pigs is therefore highly related to a disturbance of the farm ecosystem as influenced by environmental factors.

Pig herd density, measured in our study as the number of pig farms located within a $2 \mathrm{~km}$-radius area, increased the risk of having more than 2 respiratory disease outbreaks per year. This observation is in agreement with previous findings concerning Influenza viruses in pig production $[5,7$, $14,17,18]$. Therefore, a respiratory-disease outbreak might be explained by successive or simultaneous contamination by viral agents [24] related to considerable microbial exposure due to the high pig herd density. The increased microbial load on a given farm might also result from specific characteristics of that farm which were not investigated in this study (poor ventilation, immune status of the pigs...). However, 
within a high densely populated area, some factors related to the large number of pig farms in the neighbourhood might be conducive to successive contamination by viral agents if biosecurity measures are not correctly implemented on the farm level. Our results show that a high number of contacts with vehicles (animal transport, veterinarians and technicians) was a feature of farrow-to-finish farms located in the DPPA (poor biosecurity measures). Elbers et al. [6] showed that a high number of contacts (visitors associated with pig production) was linked with a high rate of H1N1 Influenza virus seropositivity on these farms. Nevertheless and because of the cross-sectional design of the survey, we should be careful in interpreting these results since pig herd density is certainly the major factor implying the other conditions such as the number of visits by veterinarians, technicians or rendering lorries. Moreover, these visitors come more often if the health situation on the farm is poor and these factors might be interpreted as consequences rather than causes. Pig herd density is therefore the main factor and affects the features of the area: a high number of small finishing units and piglet movements. Biosecurity measures at the farm level should be implemented to improve the safety of farms located in these densely populated areas: restricted access for vehicles, location of loading areas outside the farmyard perimeter, and basic hygiene measures for visitors before entering the facilities. Although the pigs remain the main factors for virus introduction via asymptomatic carriage of infectious agents, the above recommendations might help to reduce the risk of the introduction of viral and bacterial agents on pig farms.

\section{ACKNOWLEDGEMENTS}

We are grateful to the production companies, the farmers for their co-operation in this project, the veterinary services (Côtes-
d'Armor and Finistère), the "Union des Groupements de Producteurs de Viande de Bretagne" and the European Union (project FAIR5-PL97-3566) for its financial contribution. We gratefully acknowledge Dr Ian Dohoo for the critical review of the initial version of this manuscript.

\section{REFERENCES}

[1] Albina E., Epidemiology of porcine reproductive and respiratory syndrome (PRRS): an overview, Vet. Microbiol. 55 (1997) 309-316.

[2] Auvigne V., Hery D., Analysis of the relationship between seroprevalence of Aujeszky's disease and pig density within different areas of Brittany, Vet. Microbiol. 55 (1997) 153-158.

[3] Blaha T., The "colorful" epidemiology of PRRS, Vet. Res. 31 (2000) 77-83.

[4] Dohoo I.R., Ducrot C., Fourichon C., Donald A., Hurnik D., An overview of techniques for dealing with large numbers of independent variables in epidemiologic studies, Prev. Vet. Med. 29 (1996) 221-239.

[5] Elbers A.R.W., Tielen M.J.M., Cromwijk W.A.J., Hunneman W.A., Sero-epidemiological screening of pig sera collected at the slaughter house to detect herds infected with Aujeszky's disease virus, porcine influenza virus and Actinobacillus (Haemophilus) pleuropneumoniae in the framework of an Integrated Quality Control (IQC) system, Vet. Q. 12 (1990) 221-230.

[6] Elbers A.R.W., Tielen M.J.M., Cromwijk W.A.J., Hunneman W.A., Variation in seropositivity for some respiratory disease agents in finishing pigs: Epidemiological studies on some health parameters and farm and management conditions in the herds, Vet. Q. 14 (1992) 8-13.

[7] Ewald C., Heer A., Havenith U., Factors associated with influenza-A virus infections in finishing pigs, Berl. Münch. Tierärztl. Wochenschr. 107 (1994) 256-262.

[8] Greenacre M.J., Correspondence analysis in practice, Academic Press, 1993, New York.

[9] Heliez S., Auvigne V., Fourichon C., Risk factors of new Aujeszky's disease virus infection in swine herds in Brittany (France), Vet. Res. 31 (2000) 146-147.

[10] Hosmer D.W., Lemeshow S., Applied Logistic Regression, Wiley, New York, 307 p., 1989.

[11] Lebart L., Morineau A., Warwick K.W., Multivariate descriptive statistical analysis. Correspondence analysis and related techniques for large matrices, Wiley, New York, 1984.

[12] Leontides L., Ewald C., Mortensen S., Willeberg P., Factors associated with circulation of Aujeszky's 
disease virus in fattening herds of an intensively vaccinated area of Northern Germany, Prev. Vet. Med. 20 (1994) 63-78.

[13] Loeffen W.L.A., Kamp E.M., StockhofeZurwieden N., Van Nieuwstadt A.P., Bongers J.H., Hunneman W.A., Elbers A.R.W., Baars J., Nell T., Van Zijderveld F.G., Survey of infectious agents involved in acute respiratory disease in finishing pigs, Vet. Rec. 145 (1999) 123-129.

[14] Madec F., Gourreau J.M., Kaiser C., Epidemiology of swine influenza $\mathrm{H}_{1} \mathrm{~N}_{1}$ on farms in Brittany (first outbreak-1982), Epidémiologie et Santé Animale 2 (1982) 56-64.

[15] Madec F., Kaiser C., Gourreau J.M., Vannier P., Kobisch M., Paboeuf F., Aymard M., Les syndromes grippaux en porcherie d'engraissement: enquête "flash" réalisée en Bretagne, Le Point Vétérinaire 19 (1987) 654-659.

[16] Madec F., Fourichon C., Morvan P., Labbé A., Économie et santé en production porcine, INRA Prod. Anim. 5 (1992) 149-161.

[17] Maes D., Deluyker H., Verdonck M., Castryck F., Miry C., Virjens B., Dekruif A., Risk indicators for the seroprevalence of Mycoplasma hyopneumoniae, porcine influenza viruses and Aujeszky's disease virus in slaughter pigs from fattening pig herds, J. Vet. Med. Ser. B 46 (1999) 341-352.

[18] Maes D., Deluyker H., Verdonck M., Castryck F., Miry C., Vrijens B., Dekruif A., Herd factors associated with the seroprevalences of four major respiratory pathogens in slaughter pigs from farrow-to-finish pig herds, Vet. Res. 31 (2000) 313-327.

[19] Marsh W., Damrongwatanapokin T.K.L., Morrison R., The use of a geographic information system in a epidemiological study of pseudorabies (Aujeszky's disease) in Minnesota swine herds, Prev. Vet. Med. 11 (1991) 249-254

[20] McCullagh P., Nelder J.A., Log likelihood for binomial data, in: Generalized Models, 2nd ed., Chapman and Hall, London, 1989, pp. 114-119.

[21] SAS Institute Inc., SAS/STAT User's Guide, Version 6, 4th ed. 1989, Cary, NC, SAS Institute.

[22] SPAD-N, Version 4.03, ed. CISIA-CERESTA, Montreuil, France, 1999.

[23] Stegeman A., Elbers A., Van Oirschot J., Hunneman W., Kimman T., Tielen M., A retrospective study into the characteristics associated with the seroprevalence of pseudorabies virus-infected breeding pigs in vaccinated herds in the southern Netherlands, Prev. Vet. Med. 22 (1995) 273-283.

[24] Van Reeth K., Nauwynck H., Pensaert M., Dual infections of feeder pigs with porcine reproductive and respiratory syndrome virus followed by porcine respiratory coronavirus or swine influenza virus: a clinical and virological study, Vet. Microbiol. 48 (1996) 325-335.

To access this journal online: www.edpsciences.org 